\title{
SELECTION AND IDENTIFICATION OF THERMOTOLERANT ETHANOL PRODUCING YEAST STRAINS
}

\author{
Tran Thanh Phong ${ }^{{ }^{*}}$, Le Tan Hung ${ }^{1}$, Le Thi Bich Phuong ${ }^{1}$, \\ Vo Thi Hanh ${ }^{1}$, Hasashi Hoshida ${ }^{2}$, Rinji Akada ${ }^{2}$ \\ ${ }^{(1)}$ Institute of Tropical Biology, VAST, $\left.{ }^{*}\right)$ tranthanhphongitb@yahoo.com \\ ${ }^{(2)}$ Yamaguchi University, Japan
}

\begin{abstract}
Among eight yeast strains isolated from starters in Vietnam, only one strain coded as ITB3 could grow well at $45^{\circ} \mathrm{C}$ with optical density $\left(\mathrm{OD}_{660 \mathrm{~nm}}\right)$ of 3.8 that was equal to Kluyveromyces marxianus DMKU3-1042 strain $\left(\mathrm{OD}_{660 \mathrm{~nm}}\right.$ of 4$)$. At $30^{\circ} \mathrm{C}$, the strain ITB3 fermented $10 \%(\mathrm{w} / \mathrm{v})$ glucose to $4.45 \%$ $(\mathrm{v} / \mathrm{v})$ ethanol in 14 hours at a yield of $0.38 \mathrm{~g}$ ethanol $/ \mathrm{g}$ glucose, or $74.9 \%$ of theoretical yield that was slightly lower than that of $K$. marxianus DMKU3-1042 (produced $4.61 \%$ ethanol (v/v), $0.39 \mathrm{~g}$ ethanol/g glucose, or $77 \%$ of theoretical yield). However, at $45^{\circ} \mathrm{C}$, the strain ITB3 fermented $10 \%$ (w/v) glucose to $4.54 \%(\mathrm{v} / \mathrm{v})$ ethanol at a yield of $0.39 \mathrm{~g}$ ethanol $/ \mathrm{g}$ glucose, or $75.6 \%$ of theoretical yield that was slightly higher than that of K. marxianus DMKU3-1042, (produced $4.39 \%(\mathrm{v} / \mathrm{v}), 0.37 \mathrm{~g}$ ethanol/g glucose, or $72.3 \%$ of theoretical yield). The strain ITB3 was identified as $K$. marxianus ITB3 based on the results of ITS rDNA sequencing and yeast mating. These results demonstrated that the $K$. marxianus ITB 3 can be used for industrial ethanol production at high temperature in order to reduce energy consumption, especially in simultaneous saccharification and fermentation processes for production of ethanol from starchy and cellulosic materials that decreases the amount of saccharification enzymes and investment costs for a plant.
\end{abstract}

Keywords: Kluyveromyces marxianus, ethanol fermentation, thermotolerant yeasts.

\section{INTRODUCTION}

In tropical countries, the ingenious alcoholic production has been done at high temperature because the day-time temperatures are high throughout the year ranging from 30 to $37^{\circ} \mathrm{C}$. The advantages of traditional ethanol making at high temperature are rapid saccharification and fermentation, that decreased risk of contamination [5].

The starters that are used for traditional alcoholic make from rice or glutinous rice, called "Men" in Vietnamese, are produced in solid state tablets which combine two groups of microorganisms, such as, moulds and yeasts. The moulds are the major producers of amylases that degrade starch into fermentable sugars, and the yeasts convert the sugars to alcohol.

In industrial ethanol production, heat is generated at the rate of $140.2 \mathrm{cal} / \mathrm{g}$ glucose during fermentation that is controlled by cooling system. Cooling costs during the process of ethanol production are expensive. Therefore, there have been some reports on isolation, improvement and application of thermotolerant yeast strains in ethanol production at high temperature $[1,2,5]$.

Kluyveromyces marxianus is a well-known thermotolerant yeast species that can produce ethanol at high temperature and use a wide range of carbon sources [3]. K. marxianus DMKU3-1042 was found to grow and produce ethanol at $45^{\circ} \mathrm{C}$ and use carbon sources, such as, cellobiose, xylose, xylitol, arabinose, glycerol, and lactose [5].

The objectives of this study are to select yeast strains capable of growth and ethanol production at elevated temperature from starters and to identification them to species.

\section{MATERIALS AND METHODS}

\section{Yeast strains}

The strains ITB1, ITB2, ITB3, ITB4, ITB5, ITB6, ITB7 and ITB11 were isolated from starters in Vietnam; the Kluyveromyces marxianus DMKU3-1042 (KM) was isolated in Thailand [5]; and the $K$. marxianus leu2- mutant (RAK 4088) and $K$. marxianus ura5 mutant 
(RAK 4084) were selected by Yamaguchi University.

\section{Culture media}

YPD medium (1\% yeast extract, 2\%peptone and $2 \%$ glucose), and YPD10 (1\% yeast extract, $2 \%$ peptone and $10 \%$ glucose), minimal medium (MM: yeast nitrogen base without amino acids and ammonium sulfate $(1.7 \mathrm{~g} / 1)$, ammonium sulfate (5 g/l), glucose $(20 \mathrm{~g} / \mathrm{l})$, uracil $(0.08 \mathrm{~g} / 1)$, and 5-Fluoroorotic Acid (5FOA) medium.

\section{Selection of thermotolerant yeast strains}

Yeasts that isolated from starters (Men) were selected both on YPD agar at $45^{\circ} \mathrm{C}$ (the growth levels assessed as following: no-growth, weakgrowth, and good-growth), and in liquid YPD at $45^{\circ} \mathrm{C}$ (the cell growth was recorded automatically by a TVS.062CA Bio-Photorecorder (Toyo Seisakusho, Ltd., Chiba, Japan).

\section{Fermentation for ethanol production}

Forty milliliters of YPD10 medium was inoculated with an overnight YPD culture to an initial optical density at $660 \mathrm{~nm}\left(\mathrm{OD}_{660}\right)$ of 0.2 at $30^{\circ} \mathrm{C}$ and $45^{\circ} \mathrm{C}$ with shaking at $100 \mathrm{rpm}$ and without shaking. Supernatant samples were collected by centrifugation and were analyzed directly by Biosensor BF-5 (Oji Scientific Instruments, Hyogo, Japan) to determine sugar and ethanol concentrations.

\section{Yeast mating technique for identification of yeast}

First of all, the strain ITB3 was grown overnight in $2 \mathrm{ml}$ of YPD, centrifuged, washed once with sterile water, and resuspended in $1 \mathrm{ml}$ of sterile water. Aliquots $(200 \mu \mathrm{l})$ of cells were then spread on 5-FOA plates and exposed to UV for $30 \mathrm{~s}$. Colonies were picked after 2 days at $28^{\circ} \mathrm{C}$ and tested for a uracil requirement by assessing growth on MM medium with and without uracil. Then, the uracil-requiring mutants were transformed with ura3 and ura5 gene fragment by a lithium acetate method [2] to select the ITB3 ura3 $^{-}$mutant (mutation in the ura3 gene). Next, the ITB3 ura3 mutant was cross-bred with K. marxianus DMKU 3-1042 leu2- mutant and $K$. marxianus NBRC 1777 ura 5 mutant by steaking perpendicular on $2 \%$ glucose medium, the plates incubated at $28^{\circ} \mathrm{C}$ for 2 days and replicated to the MM medium without uracil by replica plating using the sterile velveteen pads. Lastly, if the colonies appear on the MM medium without uracil, the strain ITB3 is the same species to identified strains.

\section{Identification of selected strain by sequencing of the rDNA of internal transcribed spacer (ITS) region}

The ITS rDNA was amplified from genomic DNA (extracted from yeast cells) by PCR using a KOD Plus kit (Toyobo, Osaka, Japan) according to the manufacturer's instructions with forward primer ITS1 and reverse primer ITS4. The PCR was initiated at $94^{\circ} \mathrm{C}$ for $1 \mathrm{~min}$, followed by 30 cycles of the following program: $94^{\circ} \mathrm{C}$ for $20 \mathrm{~s}, 60^{\circ} \mathrm{C}$ for $30 \mathrm{~s}$, and $68^{\circ} \mathrm{C}$ for $2 \mathrm{~min}$. The PCR product was checked by agarose gel electrophoresis, purified by using ExoSAP-IT according to manufacturer's protocol and sequenced using ITS2 and ITS3 primers according to protocol of Macrogen in Japan. The ITS sequence was submitted to BLAST analysis in the National Center for Biotechnology Information nucleotide database. Yeast identification was assumed if the query sequence showed $99 \%$ identity with DNA sequences from nucleotide database.

Creation of the phylogenetic tree. A sequence file of each species was aligned using Clustalx 2.0.11 program for multiple alignment mode. The multiple-alignment file was then used to create a neighbor-joining rectangular cladogram with Treeview X 0.5.0 program.

\section{RESULTS AND DISCUSSION}

\section{Selection of thermotolerant yeast strains}

The thermotolerant growth levels of the isolates were comparable to that of KM strain on YPD agar at $45^{\circ} \mathrm{C}$. Among the isolates, the strain ITB3 was good-growth at $45^{\circ} \mathrm{C}$ (fig. 1). 

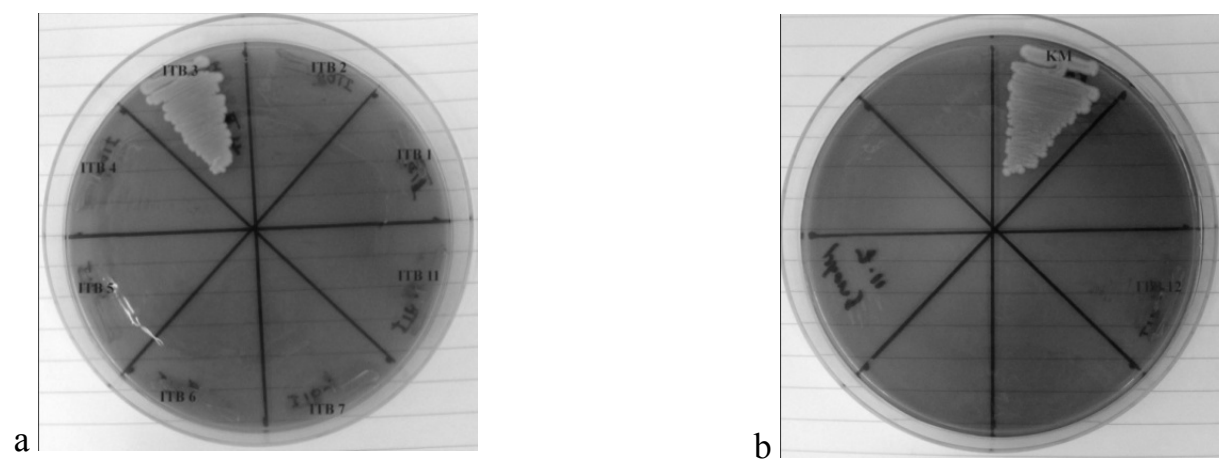

Fig. 1. The growth levels of isolates (a) and $\mathrm{KM}$ at $45^{\circ} \mathrm{C}$ (b)

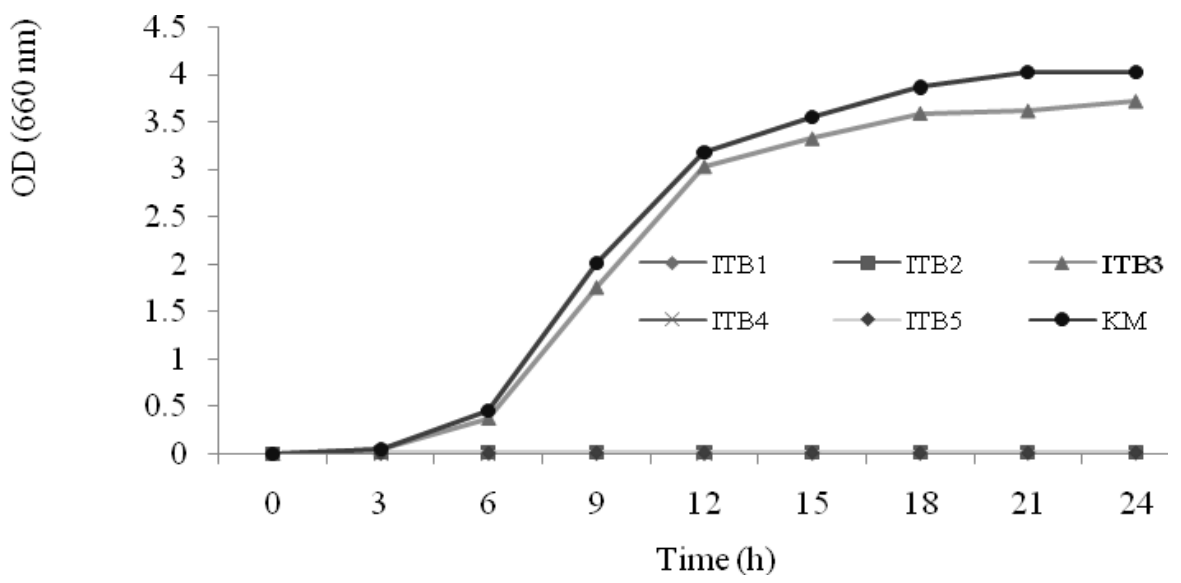

Fig. 2. Cell growth of isolates in comparision with $\mathrm{KM}$ strain at $45^{\circ} \mathrm{C}$

The cell growth of the isolates was also tested in liquid YPD at $45^{\circ} \mathrm{C}$. The result showned that the strain ITB3 could grow well at $45^{\circ} \mathrm{C}$ with $\left(\mathrm{OD}_{660 \mathrm{~nm}}\right)$ of 3.8 that was equal to $\mathrm{KM}\left(\mathrm{OD}_{660 \mathrm{~nm}}\right.$ of 4$)$ (fig. 2).

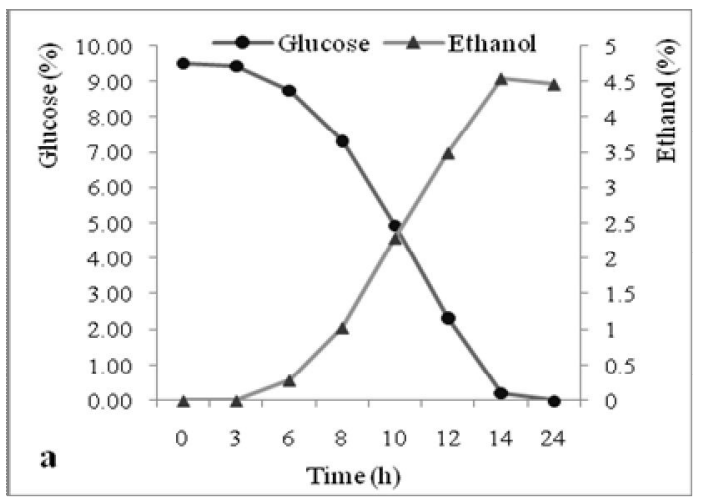

Fermentation for ethanol production by thermotolerant yeasts

The strain ITB3 was tested for ethanol production in YPD10 medium at 30 and $45^{\circ} \mathrm{C}$ with shaking at 100 rpm and compared to KM strains

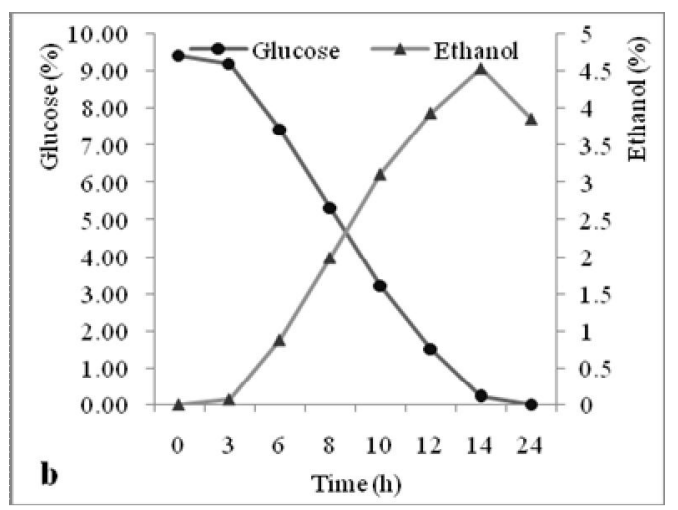

Fig. 3. Ethanol production by the strain ITB3 in YPD10 medium at $30^{\circ} \mathrm{C}$ (a) and at $45^{\circ} \mathrm{C}$ (b) 

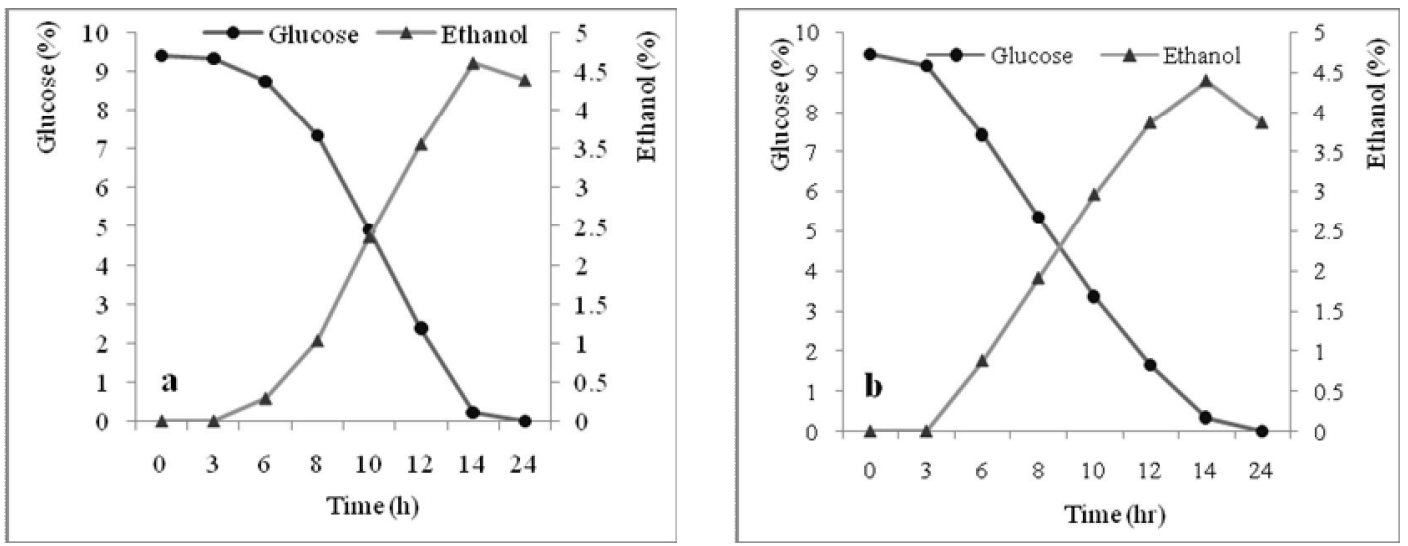

Fig. 4. Ethanol production by the strain $\mathrm{KM}$ in YPD10 medium at $30^{\circ} \mathrm{C}$ (a) and at $45^{\circ} \mathrm{C}(\mathrm{b})$

At $30^{\circ} \mathrm{C}$, the strain ITB 3 produced $4.45 \%$ $(\mathrm{v} / \mathrm{v})$ ethanol $(36.31 \mathrm{~g} / \mathrm{l})$ in 14 hours at a yield of $0.38 \mathrm{~g} / \mathrm{g}$, or $74.9 \%$ of theoretical yield that was slight lower than that of KM (produced $4.61 \%$ $(\mathrm{v} / \mathrm{v})$ ethanol $(36.9 \mathrm{~g} / \mathrm{l}), 0.39 \mathrm{~g} / \mathrm{g}$, or $77 \%$ of theoretical yield). However, at $45^{\circ} \mathrm{C}$, the ITB3 produced $4.54 \%(\mathrm{v} / \mathrm{v})$ ethanol $(36.31 \mathrm{~g} / \mathrm{l})$ at a yield of $0.39 \mathrm{~g} / \mathrm{g}$, or $75.6 \%$ of theoretical yield that was slight higher than that of KM (produced $4.39 \%(\mathrm{v} / \mathrm{v})$ ethanol $(35.11 \mathrm{~g} / \mathrm{l}), 0.37$ $\mathrm{g} / \mathrm{g}$, or $72.3 \%$ of theoretical yield ) (fig. 3 , fig. 4 and table 1).

Table 1. Ethanol production of the strain ITB3 and $\mathrm{KM}$ in YPD10 medium at $30^{\circ} \mathrm{C}$ and $45^{\circ} \mathrm{C}$ with shaking at $100 \mathrm{rpm}$ in 14 hours

\begin{tabular}{|c|c|c|c|c|c|c|}
\hline \multirow{3}{*}{ Strains } & \multicolumn{3}{|c|}{ at $30^{\circ} \mathrm{C}$} & \multicolumn{3}{c|}{ at $45^{\circ} \mathrm{C}$} \\
\cline { 2 - 7 } & $\begin{array}{c}\text { Ethanol } \\
(\mathrm{g} / \mathrm{l})\end{array}$ & $\begin{array}{c}\mathrm{g} \text { ethanol/ } \\
\text { g glucose }\end{array}$ & $\begin{array}{c}\text { \% of theor. } \\
\text { yield }\end{array}$ & $\begin{array}{c}\text { Ethanol } \\
(\mathrm{g} / \mathrm{l})\end{array}$ & $\begin{array}{c}\text { g ethanol/ } \\
\text { g glucose }\end{array}$ & $\begin{array}{c}\text { \% of theor. } \\
\text { yield }\end{array}$ \\
\hline ITB3 & 36.31 & 0.38 & 74.9 & 36.31 & 0.39 & 75.58 \\
\hline KM & 36.9 & 0.39 & 77 & 35.11 & 0.37 & 72.91 \\
\hline
\end{tabular}

Table 2. Ethanol production by the strain ITB3 and $\mathrm{KM}$ in YPD10 medium at $30^{\circ} \mathrm{C}$ and $45^{\circ} \mathrm{C}$ without shaking in 24 hours

\begin{tabular}{|c|c|c|c|c|c|c|}
\hline \multirow{2}{*}{ Strains } & \multicolumn{3}{|c|}{ At $30^{\circ} \mathrm{C}$} & \multicolumn{3}{c|}{ At $45^{\circ} \mathrm{C}$} \\
\cline { 2 - 7 } & $\begin{array}{c}\text { Ethanol } \\
(\mathrm{g} / \mathrm{l})\end{array}$ & $\begin{array}{c}\text { g ethanol/ } \\
\text { g glucose }\end{array}$ & $\begin{array}{c}\text { \% of theor. } \\
\text { yield }\end{array}$ & $\begin{array}{c}\text { Ethanol } \\
(\mathrm{g} / \mathrm{l})\end{array}$ & $\begin{array}{c}\text { g ethanol/ } \\
\text { g glucose }\end{array}$ & $\begin{array}{c}\text { \% of theor. } \\
\text { yield }\end{array}$ \\
\hline ITB3 & 21.57 & 0.23 & 46 & 27.5 & 0.3 & 59 \\
\hline KM & 24.54 & 0.28 & 54.43 & 28.9 & 0.32 & 62 \\
\hline
\end{tabular}

The strain ITB3 was also tested for ethanol fermention in YPD10 at 30 and $45^{\circ} \mathrm{C}$ without shaking at $100 \mathrm{rpm}$ and compared with $\mathrm{KM}$ strain

The results of static ethanol fermentation of both ITB3 and KM showned that the ethanol concentration was lower and the fermentation time was longer than those of shaking condition (table 2). This indicated that oxygen is a necessary factor for shorting of ethanol fermentation time of $K$. marxianus.

\section{The yeast mating for identification of unknown yeast strain}

The uracil-requiring mutants were isolated from the strain ITB3 by UV mutagenesis on 5fluoroorotic (FOA) medium (fig. 5) and the mutation was in the ura3 gene that confirmed by ura5 gene recombination (fig. 6). The ITB3 
ura3- mutant mated both $K$. marxianus leu2 ${ }^{-}$and $K$. marxianus ura5, as a result the colonies appeared on the MM medium without uracil (fig. 7). These results confirmed that the strain ITB3 was the same species with the identified mutants that belong to K. marxianus.
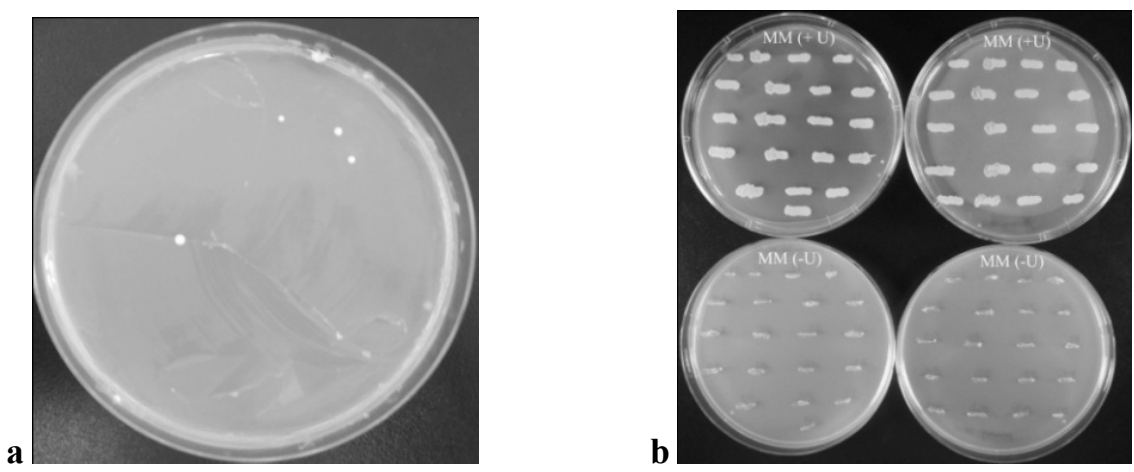

Fig. 5. The ITB3 mutants were isolated by UV mutagenesis on FoA medium (a) and required uracil for growth (b)

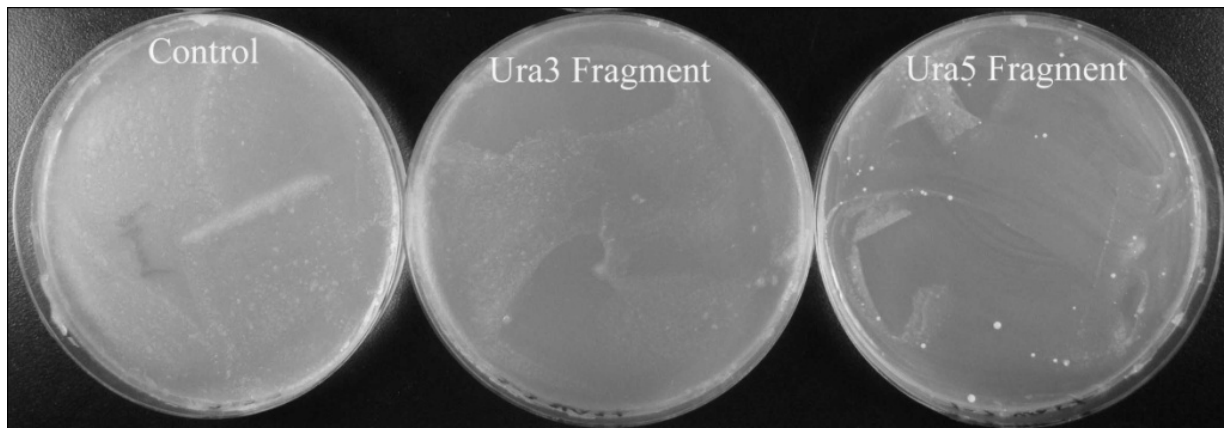

Fig. 6. The mutant was ITB3 ura3- mutant because it only recombined with ura5 fragment

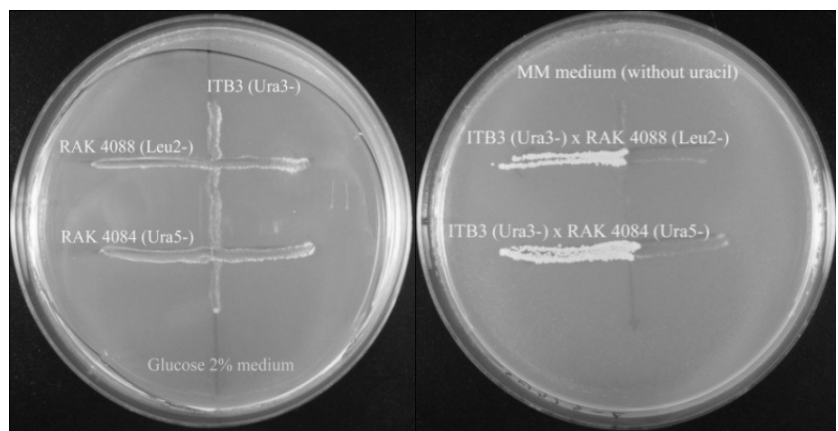

Fig. 7. The ITB3 ura3 mated with both $K$. marxianus leu2 and $K$. marxianus ura5, as a result the colonies appeared on the MM medium without uracil

Identification of selected thermotolerant yeast strain by ITS rDNA sequencing

The IBT3 strain was also identified by ITS rDNA sequencing. The results of ITS rDNA sequencing showed that the strain ITB was $100 \%$ homology to Kluyveromyces marxianus strain. Therefore, the strain ITB3 was identified as $K$. marxianus ITB3 (fig. 8). 


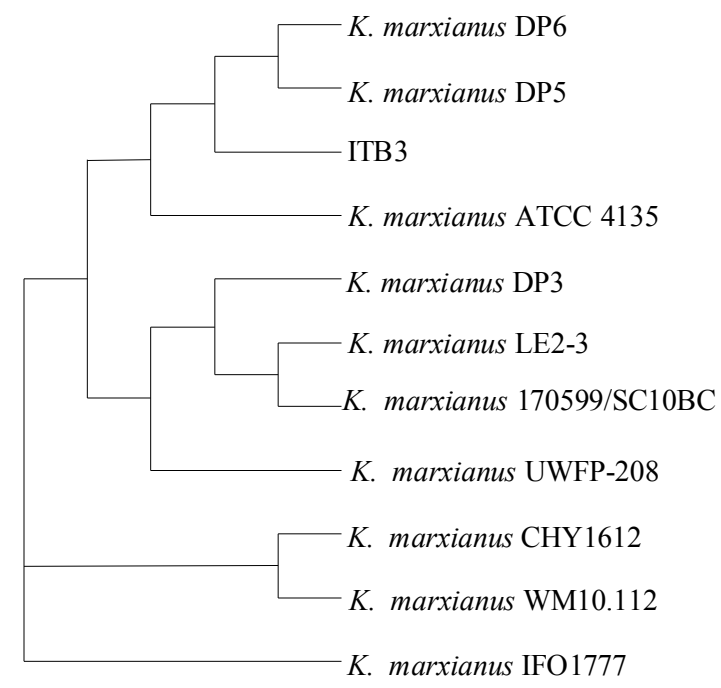

Fig. 8. Phylogenetic tree of the strain ITB3

\section{CONCLUSION}

From Vietnamese starters isolated a thermotolerant yeast (coded as ITB3) that could grow well at $45^{\circ} \mathrm{C}$ on YPD agar. The strain ITB3 was identified as $K$. marxianus ITB3 based on the results of ITS rDNA sequencing and yeast mating.

At $30^{\circ} \mathrm{C}$, the ITB3 strain produced $4.45 \%$ $(\mathrm{v} / \mathrm{v})$ ethanol in 14 hours at a yield of $0.38 \mathrm{~g} / \mathrm{g}$, or $74.9 \%$ of theoretical yield that was slight lower than that of KM (produced $4.61 \%(\mathrm{v} / \mathrm{v})$ ethanol, $0.39 \mathrm{~g} / \mathrm{g}$, or $77 \%$ of theoretical yield).

At $45^{\circ} \mathrm{C}$, the ITB3 produced $4.54 \%(\mathrm{v} / \mathrm{v})$ ethanol at a yield of $0.39 \mathrm{~g} / \mathrm{g}$, or $75.6 \%$ of theoretical yield that was slight higher than that of $\mathrm{KM}(4.39 \%(\mathrm{v} / \mathrm{v})$ ethanol, of $0.37 \mathrm{~g} / \mathrm{g}$, or $72.3 \%$ of theoretical yield).

These results shown that $K$. marxianus ITB3 can be used for industrial ethanol production at high temperature in order to reduce production cost.

Acknowledgments: We acknowledge the Asian Core Program (ACP) on "Capacity Building and Development of Microbial Potential and Fermentation Technology towards New Era" supported by the Japan Society for the Promotion of Science (JSPS) and the National Research Council of Thailand (NRCT) for the scientist exchange and collaborative research.

\section{REFERENCES}

1. Abdel-Banat B. M. A., Hoshida H., Ano A., Nonklang S., Akada R., 2010. Hightemperature fermentation: how can processes for ethanol production at high temperatures become superior to the traditional process using mesophilic yeast? Appl. Microbiol. Biotechnol., 85: 861-867, DOI 10.1007/s00253-009-2248-5.

2. Banat I. M., Nigam P., Marchant R., 1992. Isolation of thermotolerant fermentative yeasts growing at $52^{\circ} \mathrm{C} \&$ producing ethanol at $45^{\circ} \mathrm{C}$ $\& 50^{\circ} \mathrm{C}$. World J. Microbiol. Biotechnol., 8: 259-263.

3. Fonseca G. G., Heinzle E., Wittmann C., Gombert A. K., 2008. The yeast Kluyveromyces marxianus and its biotechnological potential. Appl. Microbiol. Biotechnol., 79: 339-354.

4. Gietz R. D., Woods R. A., 2002. Transformation of yeast by lithium acetate/single-stranded carrier DNA/polyethylene glycol method. Methods Enzymol., 350: 87-96.

5. Limtong S., Sringiew C., Yongmanitchai W., 2007. Production of fuel ethanol at high temperature from sugar cane juice by a newly isolated Kluyveromyces marxianus. Bioresour. Technol., 98: 3367-3374. 
6. Nonklang S., Abdel-Banat B. M. A., Chaaim K., Moonjai N., Hoshida H., Limtong S., Yamada M., Akada R., 2008. High-temperature ethanol fermentation and transformation with linear DNA in the thermotolerant yeast Kluyveromyces marxianus DMKU3-1042. Appl. Environ. Microbiol., 74: 7514-7521.

\title{
TUYỄN CHỌN VÀ ĐINHH DANH CÁC CHỦNG NẨM MEN CHỊU NHIẸT LÊN MEN ETHANOL
}

\author{
Trần Thạnh Phong ${ }^{1}$, Lê Tấn Hưng ${ }^{1}$, Lê Thị Bích Phượng ${ }^{1}$, \\ Võ Thị Hạnh ${ }^{1}$, Hasashi Hoshida ${ }^{2}$, Rinji Akada ${ }^{2}$ \\ ${ }^{(1)}$ Viện Sinh học nhiệt đới, Viện Khoa học và Công nghệ Việt Nam \\ (2) Đại học Yamaguchi, Nhật Bản
}

\section{TÓM TẮT}

Trong số tám chủng nấm men phân lập được từ men rượu, chỉ có chủng ITB3 sinh trưởng tốt ở $45^{\circ} \mathrm{C}$, với mật độ quang học (OD $660 \mathrm{~nm})$ tương đương với chủng Kluyveromyces marxianus DMKU3-1042. Ỏ $30^{\circ} \mathrm{C}$, chủng ITB3 lên men $10 \%(\mathrm{w} / \mathrm{v})$ glucose thành 4,45\% (v/v) ethanol sau 14 giờ lên men, với hiệu suất $0,38 \% \mathrm{~g}$ ethanol/g glucose, hoặc $74,9 \%$ hiệu suất lý thuyết, thấp hơn không đáng kể so với chủng KM $(4,61 \%(\mathrm{v} / \mathrm{v})$ ethanol, $0,39 \mathrm{~g}$ ethanol/g glucose, hoặc $77 \%$ hiệu suất lý thuyết). Ở $45^{\circ} \mathrm{C}$, chủng ITB3 lên men $10 \%$ (w/v) glucose thành $4,54 \%(\mathrm{v} / \mathrm{v})$ ethanol, với hiệu suất $0,39 \mathrm{~g}$ ethanol $/ \mathrm{g}$ glucose, hay $75,6 \%$ hiệu suất lý thuyết, cao hơn một chút so với chủng KM $(4,39 \%(\mathrm{v} / \mathrm{v})$ ethanol, $0,37 \mathrm{~g} / \mathrm{g}$, hoặc 72,3\% hiệu suất lý thuyết). Dựa trên kết quả so sánh trình tự rDNA ITS với ngân hàng dữ liệu DNA và lai nấm men, chủng ITB3 được định danh là Kluyveromyces marxianus ITB3.

Tù khóa: Kluyveromyces marxianus, nấm men chịu nhiệt.

Ngày nhận bài: 21-6-2012 